\title{
Inupiat Health and Proposed Alaskan Oil Development: Results of the First Integrated Health Impact Assessment/ Environmental Impact Statement for Proposed Oil Development on Alaska's North Slope
}

Aaron Wernham

Alaska Inter-Tribal Council, Fellow, Columbia University Institute on Medicine as a Profession, 2050 Cripple Creek Rd., Fairbanks, AK 99709, USA

ERRATUM TO: $10.1007 / \mathrm{s} 10393-007-$ 0132-2

The article category is incorrect on the online published version of this article. It should be Original Contribution and not Profile.

The online version of the original article can be found under doi: 10.1007/s10393007-0132-2

Published online: November 15, 2007

Correspondence to: Aaron Wernham, e-mail: aawernham@pol.net 